\title{
THE ROLE OF PRICE ELASTICITIES OF DEMAND IN THE ECONOMIC IMPACT OF A PORT
}

\author{
Joseph S. DeSalvo and Debra L. Fuller*
}

\begin{abstract}
The standard approach to estimating the economic impact of a port overestimates the port's direct impacts on exports and imports. The overestimates result because all export and import activity in the impact area is assumed to fall to zero in the absence of the port. We argue that this assumption is incorrect in general. How much exports and imports fall depends on the elasticity of demand for exports and imports. These elasticities may be infinitely large, which is what is implicitly assumed in the standard approach, but they may be less than infinity, in which case, not all of the export or import activity will be lost. We develop a methodology that explicitly accounts for the elasticity of demand for exports and imports and apply that methodology to the Port of Tampa. Comparing estimates of the direct impact using the standard methodology and ours confirms that substantial overestimates would have resulted from using the standard methodology.
\end{abstract}

\section{INTRODUCTION}

There are many economic impact studies of ports. We have compiled a bibliography of $\mathbf{4 5}$ port impact studies (available on request), and there are surely many more. There is even a quasi-official methodology. The Port Economic Impact Kit (Temple, Barker \& Sloane, Inc. et al. 1985), developed under the auspices of the U.S. Maritime Administration, is a handbook, with supporting software, for performing a port economic impact study. Sixteen of the $\mathbf{4 5}$ studies referred to above have used the Port Economic Impact Kit. In this paper, we will use the Port Economic Impact Kit as representative of standard methodology.

All port impact studies estimate the direct impacts of a port. They then apply impact multipliers, drawn from a model of the regional economy, to the direct impacts to convert direct impacts into total impacts. This paper is concerned with the appropriate way of estimating the direct impacts of a port, not with the models used to generate the impact multipliers.

Previous criticism of direct-impact estimation has focused on overestimation. Davis $(1983,62)$, among others, has decried the tendency "to include in the primary [direct] impact: (1) all economic activities located in the spatial area designated as the port, and (2) the entirety of economic activity utilizing the port facilities for exporting and importing."

*Professor of Economics, University of South Florida, and Economist, Federal National Mortgage Association, respectively. 
Concentrating on Davis's second point, we contend that the standard methodology for estimating the economic impact of a port produces overestimates of the port's direct impacts on exports and imports. The overestimate is the result of assuming that all export and import activity in the impact area would fall to zero in the absence of the port. We argue that this activity would not necessarily fall to zero and that how much it does fall depends on the elasticity of demand for exports and imports.

We develop an alternative methodology and apply it to the Port of Tampa. Comparing estimates of the direct impact using the standard methodology with ours confirms that substantial overestimates would have resulted from using the standard methodology.

In our formulation, the direct impact of a port on inland transportation also depends on the elasticities of demand for imports and exports. This is so because the change in exports and imports will affect how much inland transportation occurs. To shorten this paper, however, we deal only with the direct impacts of a port on exports and imports. Our complete study (DeSalvo and Fuller 1988) provides direct impacts of the Port of Tampa on the inland transportation industry and on the "port industry" (i.e., all port-dependent activities other than exports, imports, and inland transportation) as well as on exports and imports.

\section{METHODOLOGY}

\section{Exports}

In Figure 1, DRW represents the rest of the world's demand for the local export industry's product. There may also be a local demand for the product, but this plays no role in the analysis and is therefore omitted. We assume that the local export industry can supply the product at constant unit cost, so the supply curve, labeled S, is drawn horizontally. (This paper's methodology is independent of the regional model used to generate the impact multipliers. Nevertheless, some of the assumptions used in this paper, such as perfectly elastic industry supply, are the same as those used in input-output analysis, commonly used in port economic impact studies to model the regional economy.)

In the absence of out-of-area purchases of the export and under competitive conditions, the local export industry would sell its output at the producer price $\mathrm{P}_{0}$ in Figure 1 (the quantity sold locally is not shown). Since there is out-of-area demand for the product and since the local industry is capable of expanding its production at constant unit cost, the local industry will export the good if its 


\section{FIGURE 1}

\section{Direct Impact of a Port on Exports}

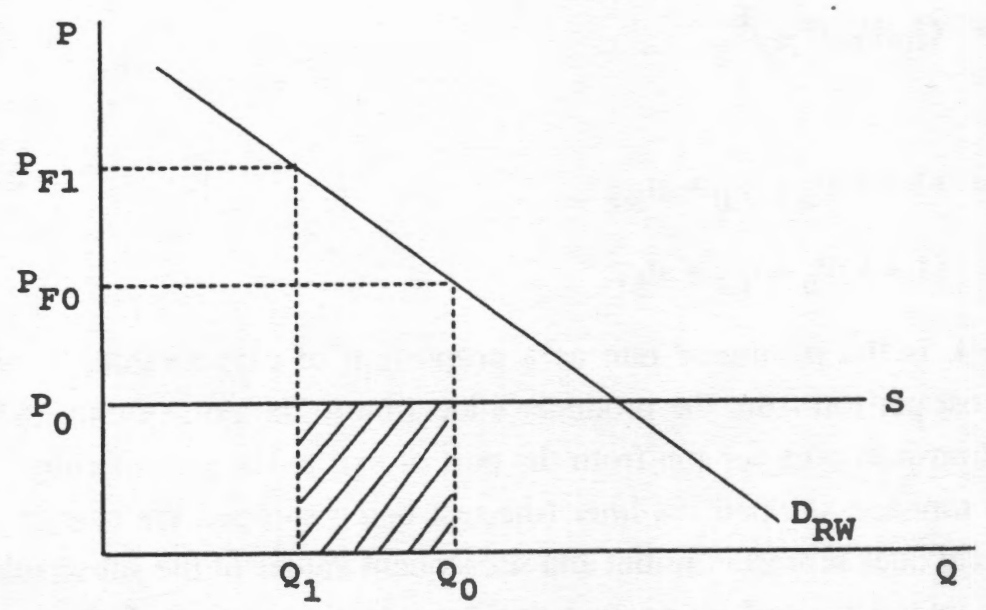

delivered price at the receiving port is equal to or less than the price of the same product available from other suppliers.

Let $P_{F 0}$ be the delivered price to a "foreign," i.e., non-local, buyer at the buyer's port of entry, where $\mathrm{P}_{\mathrm{F} O}-\mathrm{P}_{0}$ equals transportation costs incurred in moving the product from the producer's location to the buyer's port of entry, including insurance and customs duties as well as inland and overseas transportation costs per unit of output. (In this paper, "overseas" refers to all waterborne transportation, including domestic barge and domestic vessel transportation, if any.)

In Figure 1, local exporters will sell $Q_{0}$ units of the product outside the local

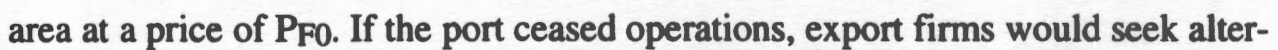
native ports from which to ship their products. This would increase inland transport costs per unit of product, and, although overseas transport costs per unit of product might rise or fall depending on the location of the alternative port, presumably per-unit total transportation costs would rise. In Figure 1, this is shown as an increase in the price to foreign buyers from $P_{F 0}$ to $P_{F 1}$. Output exported would fall from $Q_{0}$ to $Q_{1}$, the amount of the decrease in $Q_{\text {depending on }}$ the price elasticity of demand.

The direct impact of a port on exports (DIE) is the change in output valued at producer price, given graphically by the shaded area in Figure 1 or algebraically by

$$
\mathrm{DI}_{\mathrm{E}}=\mathrm{P}_{0}\left(\mathrm{Q}_{1}-\mathrm{Q}_{0}\right)
$$


If the constant-elasticity demand curve, $Q=A\left(P_{F}\right)^{E}$, where $A$ is a level parameter and $\mathrm{E}$ is the price elasticity of demand, passes through the point $\left(\mathrm{PFO}_{\mathrm{F}}, \mathrm{Q}_{0}\right)$, then

$$
\mathrm{Q}_{1}=\mathrm{Q}_{0}\left(\mathrm{P}_{\mathrm{Fl}} / \mathrm{P}_{\mathrm{FO}}\right)^{\mathrm{E}},
$$

where

$$
\begin{aligned}
& P_{F 0}=(1+k) P_{0}+t_{L 0}+a t_{S 0}, \\
& P_{F 1}=(1+k) P_{0}+t_{L 1}+a t_{S 1},
\end{aligned}
$$

and where $\mathbf{k}$ is the insurance rate as a proportion of cargo value, th is inland transport cost per ton from the producer's location to the port of exit, ts is overseas liner transport cost per ton from the port of exit to the port of entry, a is the fraction of tonnage shipped via liner (the rest being shipped via charter vessel), and zeros and ones represent initial and subsequent values of the subscripted variables. (We intend tso and ts 1 to represent transportation rates of all waterborne vessels including domestic barges and vessels.)

The appearance of the liner proportion, $a$, in Equation (1) requires some justification. Suppose a shipper uses a shipping line for transporting 80 percent of his cargo tonnage and uses charter vessels for the remaining 20 percent. Then the cost of shipping an additional ton is $\mathbf{8 0}$ percent of the liner rate per ton (i.e., 0.8 ton goes via liner, and 0.2 ton, by charter vessel, but the additional cost of the charter is zero, assuming the charter vessel is not already at capacity). Hence, in the estimation formula, the liner rate is multiplied by the proportion of tonnage shipped by liner. More formally, if both liner and charter vessels are used, the total cost of getting the exporter's product to market is

$$
C=P_{0} Q+t_{S}(a Q)+T_{S}+t_{L} Q+k P_{0} Q \text {, }
$$

where, in addition to the variables defined above, Ts is the cost of chartering a vessel. Marginal cost is

$$
M C=(1+k) P_{0}+a t_{S}+t_{L} .
$$

(If $\mathrm{a}=1$, then $\mathrm{Ts}=0$, and $\mathrm{MC}=(1+\mathrm{k}) \mathrm{P}_{0}+\mathrm{ts}+\mathrm{t}$.) Under competitive conditions, this is also the price paid by the buyer at the foreign port, or $\mathrm{PF}$.

In the absence of the local port, the delivered foreign price of local exports would be PF1. If rest-of-world demand were either perfectly elastic at PF0 or at least more elastic than depicted in Figure 1, such that it intersected the price axis at or below $\mathrm{P}_{\mathrm{Fl}}$, then the quantity of local exports demanded by the rest of the 
world would be zero. No exports would occur. Under this circumstance, $\mathrm{DIE}_{\mathrm{E}}=\mathrm{PQ}_{0}$, that is, the direct impact would be the loss of the entire quantity formerly exported. This is what is implicitly assumed in most port economic impact studies. Hence, the economic impact of a port on exports is typical ly overestimated.

\section{Imports}

In Figure 2, D represents the demand in the impact area for an imported good. (The import is assumed to be noncomparable, i.e., the same product is not produced locally. We return to this point later.) Local demand depends on the local delivered price, which consists of domestic port value plus inland transport costs per unit of product. Domestic port value, in turn, is equal to the producer price of the export plus insurance, customs duties, and overseas transport costs, all expressed per unit of the product.

FIGURE 2

Direct Impact of a Port on Imports

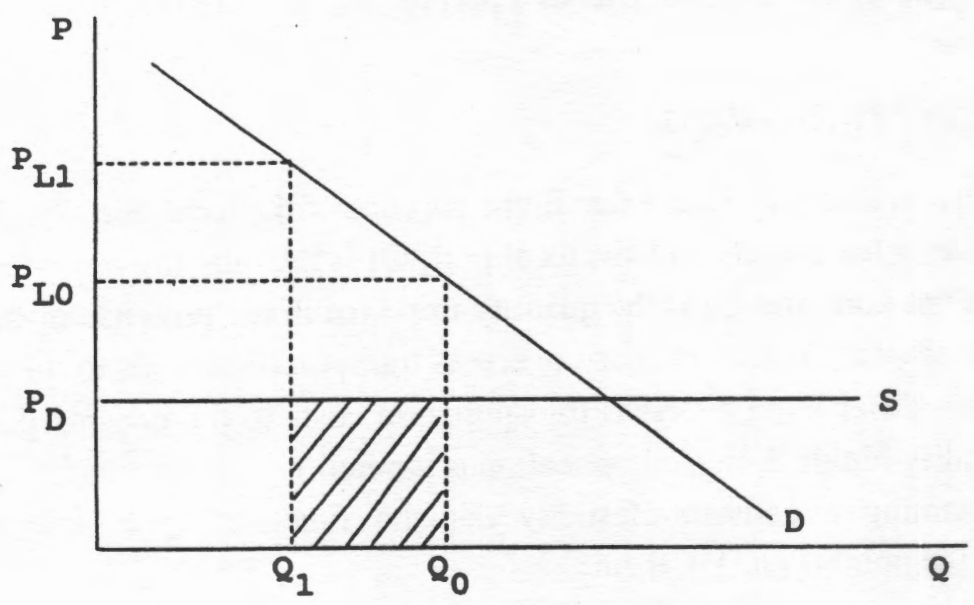

Let $P_{L 0}$ be the local delivered price and $P_{D}$ be domestic port value per unit. In Figure 2, at price PLO, $Q_{0}$ units are sold to local importers. In the absence of the port, inland (and perhaps overseas) transport costs per unit of product shipped would be increased, and local delivered price would rise. In Figure 2, this higher local price is $P_{\mathrm{L} 1}$, at which quantity demanded is $\mathrm{Q}_{1}$.

Since it is customary to value imports at domestic port value, the direct impact is the shaded area in Figure 2. Note that in this case, as opposed to the case of 
exports, the direct impact is the decrease in the quantity imported, rather than the decrease in the quantity produced. Nevertheless, the increase in price of imported goods into the local area and the consequent reduction in their use will adversely affect local output since the imports are used as inputs to local production or are distributed by local wholesalers and retailers.

Although this paper deals with the estimation of direct impacts, not total impacts, it might be useful to note how the direct impact as defined above could be converted into a total impact, as well as noting an alternative approach. Since we define the direct impact of noncomparable imports as the change in imports, rather than the change in production, we used input-output supply multipliers to obtain the total impacts in our study of the Port of Tampa (DeSalvo and Fuller 1988, 119-121, 138-161, 299-305, 313-319, 327-333, 348-361, 369-375). (For a discussion of input-output supply multipliers, see Miller and Blair (1985, 317322). Davis $(1983,66-68,77)$, on the other hand, suggests defining the direct impact as the change in the output of local industries and applying a "total-output multiplier" to get the total impact. Either way is possible, and we have discussed both elsewhere (DeSalvo and Fuller 1988, 185-190). However, the approach presented in this paper is simpler and requires less data than the alternative.

In general, the direct impact of a port on imports (DIM) is

$$
\mathrm{DI}_{\mathrm{M}}=\mathrm{P}_{\mathrm{D} 1} \mathrm{Q}_{1}-\mathrm{P}_{\mathrm{D} 0} \mathrm{Q}_{0} \text {, }
$$

where $\mathrm{PD}_{\mathrm{D} 1}$ is domestic port value in the absence of the local port, $\mathrm{PD}_{\mathrm{D}}$ is domestic port value in the presence of the local port, $Q_{1}$ is the quantity imported in the absence of the port, and $Q_{0}$ is the quantity imported in the presence of the port. The PD's are allowed to vary because overseas transportation costs to the new port of entry may differ from overseas transportation costs to the original port of entry. (To simplify Figure 2, this complication is ignored.)

Assuming a constant-elasticity demand function, $\mathrm{Q}=\mathrm{A}\left(\mathrm{PL}_{\mathrm{L}}\right)^{\mathrm{E}}$, passing through the point $\left(\mathrm{PLO}_{\mathrm{L}} \mathrm{Q}_{\mathrm{O}}\right)$, then

$$
\mathrm{Q}_{1}=\mathrm{Q}_{0}\left(\mathrm{P}_{\mathrm{L} 1} / \mathrm{P}_{\mathrm{LO}}\right)^{\mathrm{E}},
$$

where

$$
P_{L O}=P_{D O}+t_{L O}
$$

and

$$
P_{L 1}=P_{D 1}+t_{L 1}
$$


Customs duties may be levied as either a percentage of cargo value or as a fixed amount per ton, and the estimable forms for the direct impact of imports will differ slightly depending on which method is used. When customs duties are levied per dollar of value,

$$
P_{D 0}=\left(1+k+c_{v}\right) P_{0}+a_{s 0}
$$

and

$$
P_{D 1}=\left(1+k+c_{v}\right) P_{0}+a t_{S 1} \text {. }
$$

When customs duties are levied as an amount per cargo ton,

$$
P_{D 0}=(1+k) P_{0}+c_{q}+a t_{S 0},
$$

and

$$
P_{D 1}=(1+k) P_{0}+c_{q}+a_{S 1} .
$$

In the absence of the local port, the delivered local price of imports would be $P_{L 1}$, which is greater than $P_{L O}$. If local demand were either perfectly elastic at $P_{L O}$ or at least more elastic than depicted in Figure 2, such that it intersected the price axis at or below $\mathrm{PL}_{1}$, then the quantity of imports locally demanded would be zero. None of the product would be imported into the local area, and $\mathrm{DI}_{M}=\mathrm{PDOQ}_{\mathrm{D}}$, that is, the direct impact would be the loss of the entire quantity formerly imported. This is what is implicitly assumed in most port economic impact studies. Hence, the economic impact of a port on imports is typically overestimated.

We are ignoring comparable imports, i.e., products identical to those produced in the impact area. The increased price of comparable imports into the impact area raises the price of locally produced substitutes, which, given upward sloping supply, results in increased local production. Thus, to exclude comparable imports when they existed would result in an underestimation of the direct, and total, impact of the port. We ignore comparable imports because there were none during the period to which our data apply, and it is likely that if researchers have access to disaggregated data, such as we did, they may find no comparable imports for their impact areas. The impact estimation formula in the case of comparable imports may be found in DeSalvo and Fuller (1988, 191-195). 


\section{APPLICATION}

The variables necessary to estimate the direct impacts of a port on both exports and imports are producer price $\left(\mathrm{P}_{0}\right)$, initial quantity exported or imported $\left(Q_{0}\right)$, price elasticity of demand $(E)$, insurance as a proportion of value $(k)$, initial and subsequent inland transport costs per ton (tLo and tL1), initial and subsequent overseas liner costs per ton (tso and ts1), and the proportion shipped via liner (a). In addition, for imports, we also need customs duties per dollar of value $\left(c_{v}\right)$ and as a dollar amount per ton $\left(c_{q}\right)$.

\section{Producer Price $\left(\mathbf{P}_{0}\right)$ and Quantity Exported or Imported $\left(\mathbf{Q}_{0}\right)$}

We obtained the declared value of each commodity exported from and imported into the Port of Tampa in fiscal year 1985-86 from the U.S. Department of Commerce (1986a). These highly disaggregated data were aggregated into categories conforming to those in the Port Authority's fiscal year 1985-86 cargo report (Port of Tampa 1986). With minor exceptions, quantities exported and imported were taken from the Port Authority's fiscal year 1985-86 cargo report.

Aggregated values were divided by aggregated quantities for each group of exports and imports to obtain unit value, a proxy for producer price. Unit values and quantities may be found in DeSalvo and Fuller (1988, 58-59, 81-82). (To keep this paper to a reasonable length, we shall provide only data that are likely to be of general interest.)

\section{Price Elasticity of Demand (E)}

We used published price elasticities from constant-elasticity demand functions, where available, adjusted for market share. There are more constant-elasticity estimates than others, and the use of constant elasticities avoids the necessity of assuming that the price-quantity point at which the reported elasticity is evaluated corresponds to the price-quantity combination in our data. That is why the estimable forms presented above assume constant elasticities. In those cases where there was no constant-elasticity estimate, we used whatever was available, generally an estimate from a linear demand function.

Table 1 presents some of the elasticities used in our study. The ones given in Table 1 are for those commodities whose quantities exported or imported would not have fallen to zero in the absence of the Port of Tampa (this is discussed further later). The remaining elasticities may be found in DeSalvo and Fuller (1988, $62,84,226,236$ ). In Table 1, the first column is the commodity for which the published price elasticity was estimated. The second column presents the publish- 


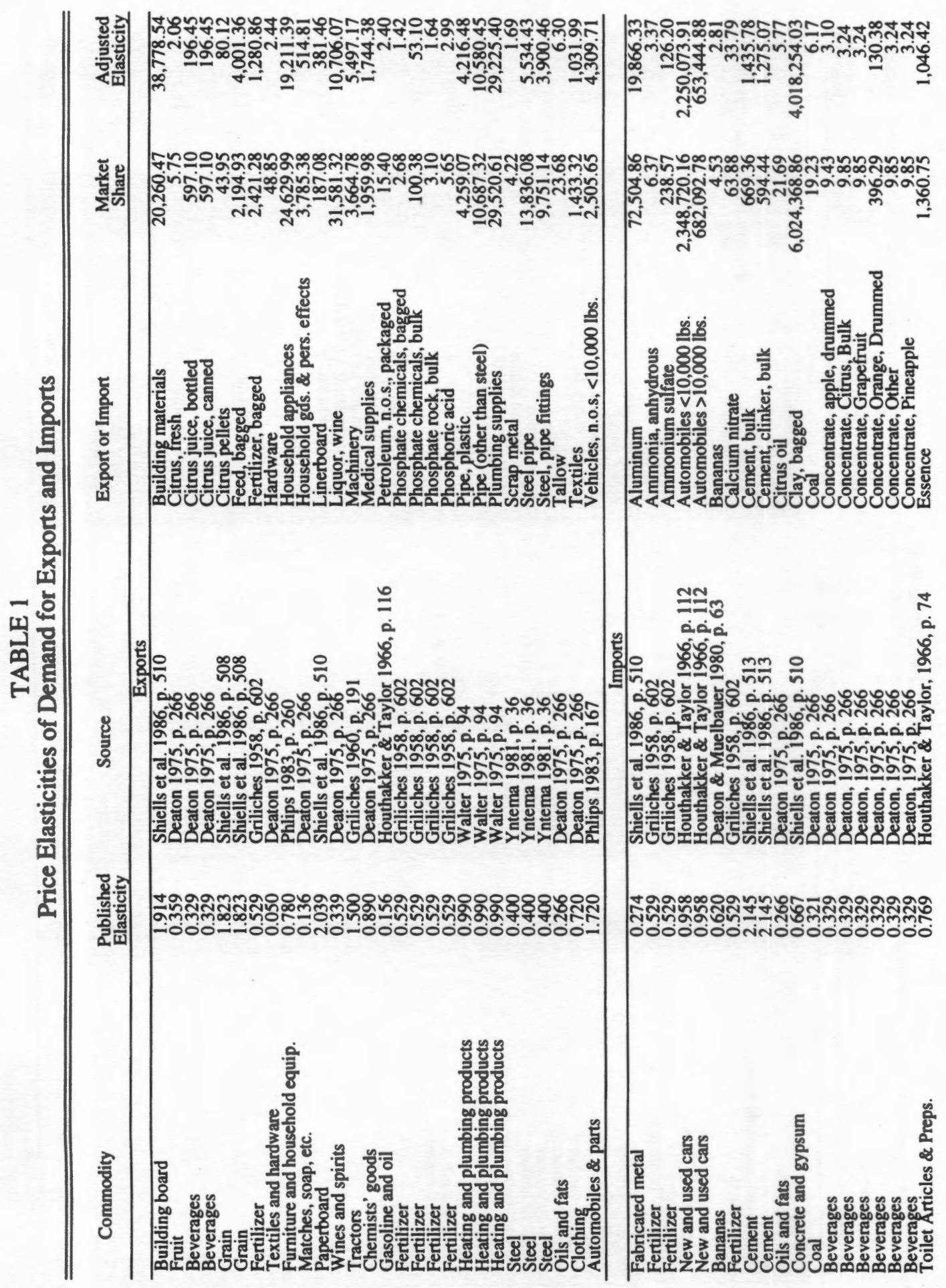




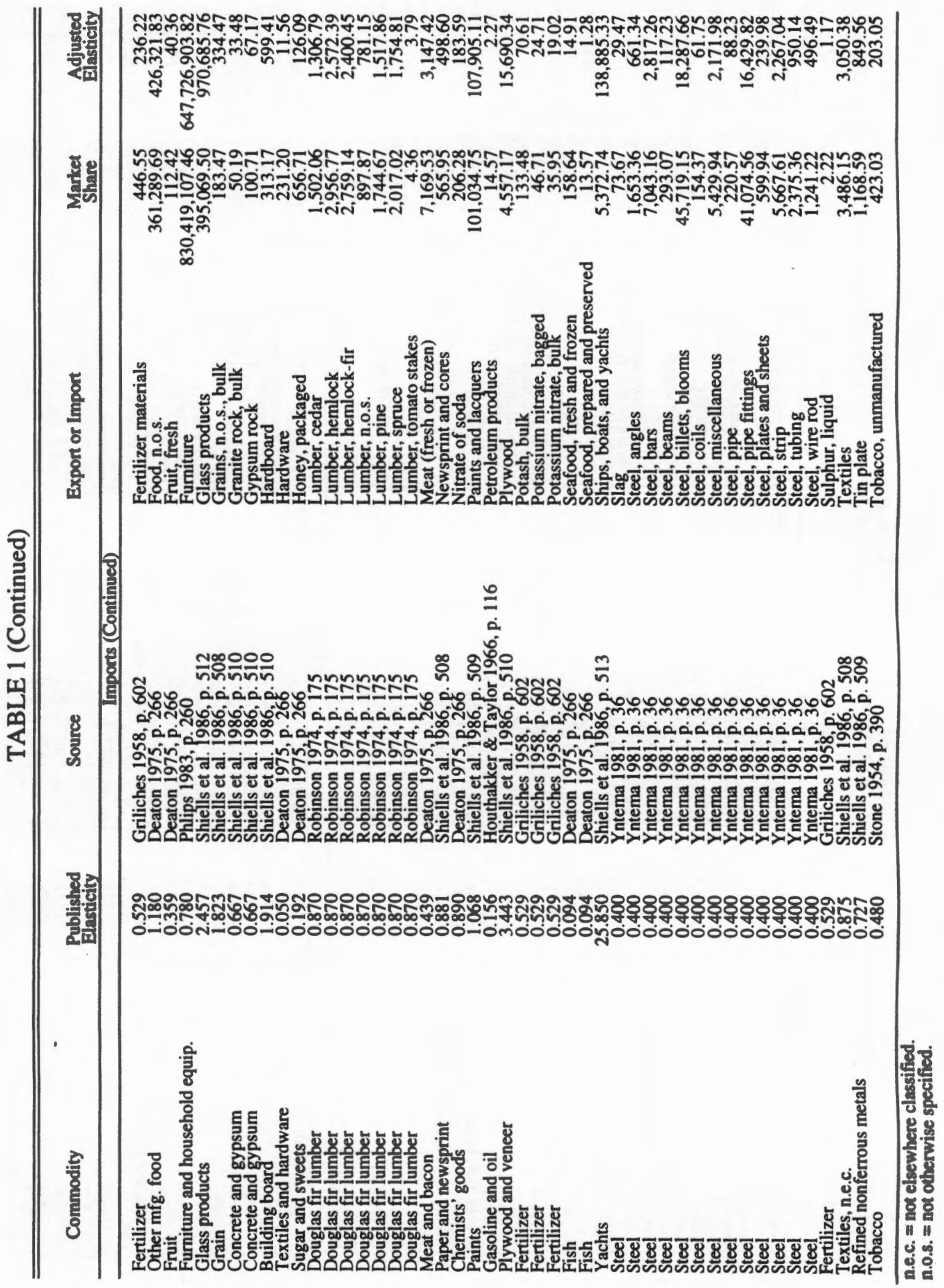


ed elasticities. The third column provides the source of the published elasticity. The fourth column lists the exported or imported commodity as described in the Port of Tampa's cargo report (Port of Tampa 1986).

Conversations with Port of Tampa personnel were very useful in helping us associate the commodities used in the published studies with the Port's exports and imports. Nevertheless, some of the associations are a bit strained, e.g., associating the commodity class, "matches, soap, etc." with the export, "house hold goods and personal effects."

Because the published elasticities were estimated for the United States or the United Kingdom, they are not directly applicable to our impact area, which consists of five contiguous counties in the Tampa Bay area. To obtain elasticities relevant to our impact area, we adjusted the published elasticities by a marketshare factor. This converted the published elasticities into elasticities that reflect the responsiveness of non-impact-area buyers to changes in prices of impact-area exports and the responsiveness of local imports to changes in delivered price in the impact area.

To obtain the requisite elasticities, a relationship between market demand elasticity and market share must be hypothesized. To capture this idea, let

$\mathbf{P}=\mathbf{P}(\mathbf{Q})$

be the world inverse demand function, where $\mathrm{P}$ is price and $\mathrm{Q}$ is world sales (i.e., output). The change in world price with respect to a change in output produced by firms in the ith region (for exports) or output purchased by firms in the ith region (for imports) is

$$
\begin{aligned}
\mathrm{dP} / \mathrm{dq} q_{i} & =(\mathrm{dP} / \mathrm{dQ})\left(\mathrm{dQ} / \mathrm{dq}_{\mathrm{i}}\right) \\
& =\mathrm{dP} / \mathrm{dQ},
\end{aligned}
$$

where $\mathrm{q}_{\mathrm{i}}$ is the output produced by or purchased by firms in the ith region and $\Sigma q_{i}=Q$. Multiplying both sides of the preceding equation by $q_{i} / P$ and the righthand side by $\mathrm{Q} / \mathrm{Q}$ yields, upon rearranging,

$$
\left(q_{i} / P\right)\left(d P / d q_{i}\right)=\left(q_{i} / Q\right)(Q / P)(d P / d Q),
$$

or, assuming $\mathrm{P}(\mathrm{Q})$ is invertible,

$$
E_{i}=E / s_{i},
$$

where $E_{i}$ is the ith regions's price elasticity of demand, $E$ is the world price elasticity of demand, and $s_{i}=q_{i} / Q$ is the ith region's share of world output sold (in the case of exports) or bought (in the case of imports). The relationship derived here may be found in Maurice and Phillips (1992, 546-547); however, their derivation uses linear demand, whereas ours is general. 
As noted earlier, all the empirical price elasticities used in this study were estimated either for the United States or the United Kingdom, so the $E_{i}$ and $s_{i}$ in the preceding equation refer to U.S. or U.K. elasticities and shares. Consequently, we had to convert these elasticities and shares to make them representative of the much smaller geographical area constituting our impact area.

Rearranging the preceding equation, we have

$$
\mathrm{E}=\left(\mathrm{E}_{\mathrm{i}}\right)\left(\mathrm{s}_{\mathrm{i}}\right),
$$

then

$$
\mathrm{E}_{\mathrm{T}}=\mathrm{E} / \mathrm{s}_{\mathrm{T}}=\left[\left(\mathrm{E}_{\mathrm{i}}\right)\left(\mathrm{s}_{\mathrm{i}}\right)\right] / \mathrm{s}_{\mathrm{T}},
$$

where $E_{\mathrm{T}}$ is the price elasticity of world demand for the Tampa impact area's exports or the price elasticity of the Tampa impact area's demand for imports, and ST is the Tampa impact area's sales (for exporters) or purchases (for importers) as a share of world sales (for exporters) or purchases (for importers).

When estimating export demand elasticities for our impact area, we used the U.S.'s or U.K.'s share of world production as $\mathrm{s}_{\mathrm{i}}$ and the Tampa impact area's exports as a share of world production as ST. The use of world production in lieu of world sales assumes no end-of-year inventories. The use of the impact-area's exports instead of impact-area sales assumes that all production of impact-area exports is sold outside the impact area.

When estimating import demand elasticities for our impact area, we used the U.S.'s or U.K.'s share of world consumption as $s_{i}$ and the Tampa impact area's imports as a share of world consumption as sT. World consumption is, by definition, equal to world purchases. We used "apparent consumption," defined by the United Nations as world production less exports plus imports. The use of impactarea imports in lieu of impact-area purchases assumes that impact-area imports are all noncomparable (i.e., there is no local production of imported goods).

Geographical area production figures came from the Department of International Economic and Social Affairs, Statistical Office of the United Nations (1986, various pages). Geographical area export and import values came from the Department of International Economic and Social Affairs, Statistical Office of the United Nations (1987, various pages), the Commodity Research Bureau (1987, 21, 188, and 211), and the U.S. Department of Commerce (1986c, 660, 726, and 727).

Column 5 of Table 1 provides the market-share factor, $\mathrm{si} / \mathrm{sT}$, which, when multiplied by the published elasticity, produces the adjusted elasticity given in column 6 of Table 1. It is these elasticities we used in the study. Data on apparent consumption of exports and imports, Port of Tampa export and import value, and 
their ratios for all commodities passing through the Port of Tampa in fiscal year 1985-86 may be found in DeSalvo and Fuller (1988, 227-228, 237-238).

The smallest elasticity in column 6 is 1.17 for liquid sulphur, a domestic vessel import from Louisiana, used as an input into the production of fertilizer of which the Tampa Bay area is a major world supplier. The largest elasticity is $647,726,904$ for imported furniture, for which the Tampa Bay area is obviously not a major market (more on this particular elasticity later). Many of the elasticities in Table 1 are quite large but were left in the table if the quantity demanded of the commodity to which they relate would not have fallen to zero in the absence of the Port of Tampa. This will be discussed further later.

\section{Insurance (k) and Inland Transport Rates (tLO, tL1)}

According to maritime insurance industry personnel we interviewed in Tampa, cargo insurance on most goods is charged at the rate of 1 percent of the value of the commodity, regardless of destination. Insurance costs therefore will not vary with the port of exit, but with the value of the cargo. Essentially, insurance costs act to raise the producer price by 1 percent.

The estimation of inland transport rates (tLo and $t_{L 1}$ ) was more complicated. Based on interviews with personnel of the five ports closest to Tampa, we estimated unused capacity available to handle cargo exported from the Port of Tampa in fiscal year 1985-86. Consideration was given to type of cargo, e.g., some ports did not have refrigerated facilities and some would not have handled toxic chemicals. The estimated unused capacities may be found in DeSalvo and Fuller (1988, 229-230).

We then estimated the tonnages exported from each county in the impact area and the average distances those exports needed to be shipped to the Port of Tampa and to the alternative ports. With the aid of several freight forwarders, each export manufactured in or distributed from the impact area was categorized by SIC code according to the principal business activity of the exporter. For these exports, we used data from the Florida Department of Labor and Employment Security (1985-86) to determine the number of establishments in each industry and county of the impact area.

The number of establishments in each county was then expressed as a percentage of the total number of establishments by industry. This percentage was used to estimate the tonnage of each commodity exported from each county in our impact area. We measured the distances in miles from the midpoint of each county in our impact area to the Port of Tampa from maps of the local area. The estimated tonnages and distances may be found in DeSalvo and Fuller (1988, 231-233). 
For commodities traveling over land by truck, we obtained inland transportation rates by commodity class code for various truck load sizes and for various distances. These data were obtained from American Freight Systems, a trucking firm with freight rates available on computer. These rates were then converted into rates per ton. For commodities traveling over land by rail, we obtained rates per ton from various origins and destinations from CSX Transport and Georgia Freight Bureau.

A weighted average inland transportation rate was calculated for all shipments from counties in the impact area to the Port of Tampa. The rate from the midpoint of each county to the port was weighted by the percentage of the product produced in each county. A similar procedure was used to calculate a weighted average inland transportation rate for each commodity to each alternative port from the counties in the impact area. These rates were multiplied by the percentage of unused capacity at the respective alternative ports for the good in question and summed to obtain the weighted average cost per ton of transporting a good from the county of production or distribution to an alternative port of exit. The estimated rates may be found in DeSalvo and Fuller (1988, 70-71).

Similar procedures were used to estimate inland transport rates on imports. Based on estimates of unutilized capacity, cargo tonnages that could have been handled by alternative ports in the absence of the Port of Tampa were calculated. Each import was assigned an SIC code based on the principal business activity of users of imported commodities. Florida Department of Labor establishment data were used to estimate the number of establishments in each industry and county of the impact area. The number of establishments in each county was expressed as a percentage of the total number of establishments by industry, and it was assumed that these percentages represented the distribution of imported goods used by each industry in each county. The cost per ton of transporting each import overland from the Port of Tampa and from each alternative port was estimated as a weighted average, as in the case of exports. The component estimations and resulting transport rates may be found in DeSalvo and Fuller $(1988,87-88,239-$ 242).

\section{Overseas Transport Rates (tso and ts1), Proportion Liner (a), and Customs Duties ( $c_{v}$ and $\left.c_{q}\right)$}

To calculate the per-ton liner rate for shipping commodities overseas from the Port of Tampa and from alternative ports, we first determined the country importing the product or, if more than one country, the country importing the largest quantity (Port of Tampa 1986). We then obtained shipping rates to each country from a variety of sources (The Florida Shipper 1987; Shipping Digest 1987; The 
Journal of Commerce and Commercial Shipyards 1987; and personal interviews with personnel of Nexos Lines, Inc., and Hamilton Brothers, Inc.). These data may be found in DeSalvo and Fuller $(1988,234-235)$.

The rate in the absence of the Port of Tampa was calculated as a weighted average of liner rates by commodity. The weights were the percentages of unutilized capacity of the alternative ports in fiscal year 1985-86, which had already been estimated for use in estimating inland transport rates. The resulting rates may be found in DeSalvo and Fuller (1988, 73-74).

Similar procedures were used for imports. For those imports for which tonnage was moved via liner, we determined the most frequent port of origin of imports entering our impact area (U.S. Department of Commerce 1986b). The country exporting the largest amount of each commodity imported into the local area was considered to be the country of origin for that item. Liner rates were obtained as for exports. The supporting estimates and resulting rates may be found in DeSalvo and Fuller (1988, 90- 91, 243-244).

The liner rate in the absence of the Port of Tampa was calculated as a weighted average of liner rates by commodity: the percentage of each commodity entering each alternative port, based on unutilized capacity in fiscal year 1985-86, was multiplied by the freight rate associated with that alternative port and summed, by import commodity, over all alternative ports.

Using Port Authority data showing shipment tonnages by commodity and by vessel in fiscal year 1985-86 (Port of Tampa 1986), we calculated the percentage of each commodity shipped via liner. The data on liner rates and percent liner may be found in DeSalvo and Fuller (1988, 90-91).

Customs duties were provided by the District Director of the U.S. Customs Office in Tampa.

\section{RESULTS}

Tables 2 and 3 present our results. Table 2 deals with exports, and Table 3 deals with imports. The stub of Table 2 lists all commodities exported from the Port of Tampa during fiscal year 1985-86. Likewise, the stub of Table 3 lists all commodities imported into the Port of Tampa during the same period. Column 1 in each table presents the direct impacts as estimated by the standard method. Column 2 of each table presents the direct impacts as estimated by our method. In each table, column 3 gives the dollar overestimate of the standard approach, while column 4 gives the percentage overestimate. The commodities for which the overestimate in column 3 is zero are those for which the standard method and our method yield the same result, or for which the standard method's implicitly as- 
TABLE 2

Direct Impact of the Port of Tampa on Exports, FY 1985-86

Standard Method vs. Our Method

\begin{tabular}{|c|c|c|c|c|}
\hline \multirow[b]{2}{*}{ Commodity } & \multicolumn{2}{|c|}{ Direct Impact } & \multicolumn{2}{|c|}{ Overestimate } \\
\hline & $\begin{array}{c}\text { Standard Method } \\
(\boldsymbol{S})\end{array}$ & $\begin{array}{l}\text { Our Method } \\
(\boldsymbol{S})\end{array}$ & $\begin{array}{l}\text { Stan } \\
(\boldsymbol{S})\end{array}$ & $\begin{array}{r}\text { d Method } \\
\text { (\%) }\end{array}$ \\
\hline Alcohol, denatured, drummed & 44,149 & 44,149 & 0 & 0 \\
\hline Asphalt, packaged & 183,610 & 183,610 & 0 & 0 \\
\hline Automobile(s) $10,000 \mathrm{lbs}$. & $1,464,577$ & $1,464,577$ & 0 & 0 \\
\hline Automobile(s) 10,000 lbs. & 477,598 & 477,598 & 0 & 0 \\
\hline Batteries & $\mathbf{8 , 9 9 8}$ & 8,998 & 0 & 0 \\
\hline Building materials & 938,934 & 938,537 & 397 & 0 \\
\hline Canned goods & 73,803 & 73,803 & 0 & 0 \\
\hline Cattle, live & $5,077,411$ & $5,077,411$ & 0 & 0 \\
\hline Caustic soda & 12,195 & 12,195 & 0 & 0 \\
\hline Cement, bagged & 1,515 & 1,515 & 0 & 0 \\
\hline Chemicals, packaged & $1,963,832$ & $1,963,832$ & 0 & 0 \\
\hline Citrus, fresh & $28,023,981$ & $1,833,826$ & $26,190,155$ & 1,428 \\
\hline Citrus juice, bottled & 140,449 & 41,700 & 98,749 & 237 \\
\hline Citrus juice, canned & 109,594 & 54,802 & 54,792 & 100 \\
\hline Citrus oil & 7,511 & 7,511 & 0 & 0 \\
\hline Citrus pellets & $67,349,096$ & $52,305,079$ & $15,044,017$ & 29 \\
\hline Commodities, n.o.s., packaged & $28,852,867$ & $28,852,867$ & 0 & 0 \\
\hline Concrete products & 1,138 & 1,138 & 0 & 0 \\
\hline Electrical equipment & 414,105 & 414,105 & 0 & 0 \\
\hline Feed, bagged & $1,724,569$ & $1,724,521$ & 48 & 0 \\
\hline Fertilizer, bagged & 321,235 & 0 & 321,235 & 0 \\
\hline Flour and meal, bagged & 72,102 & 72,102 & 0 & 0 \\
\hline Food, n.o.s. & 962,522 & 962,522 & 0 & 0 \\
\hline Fruit, fresh & 107,955 & 107,955 & 0 & 0 \\
\hline Fruit, frozen & 5,796 & 5,796 & 0 & 0 \\
\hline Fruit juice, canned & 2,333 & 2,333 & 0 & 0 \\
\hline Furniture & 126,658 & 126,658 & 0 & 0 \\
\hline Gypsum wallboard & 37,373 & 37,373 & 0 & 0 \\
\hline Hardboard & 12,158 & 12,158 & 0 & 0 \\
\hline Hardware & $1,919,006$ & 6,613 & $1,912,393$ & 28,918 \\
\hline Hides \& skins & 9,149 & 9,149 & 0 & 0 \\
\hline Household appliances & 749,916 & 749,913 & 3 & 0 \\
\hline Household goods \& personal effects & 967,781 & 490,411 & 477,370 & 97 \\
\hline Insecticides \& fungicides, packaged & $10,877,692$ & $10,877,692$ & 0 & 0 \\
\hline Linerboard & $6,367,631$ & $6,131,238$ & 236,393 & 4 \\
\hline Liquor, beer & 219,823 & 219,823 & 0 & 0 \\
\hline Liquor, wine & 21,767 & 21,765 & 2 & 0 \\
\hline Lube oil, packaged & 765,367 & 765,367 & 0 & 0 \\
\hline Lumber, cedar & 2,243 & 2,243 & 0 & 0 \\
\hline Lumber, n.o.s. & 32,557 & 32,557 & 0 & 0 \\
\hline Lumber, pine & 388,236 & 388,236 & 0 & 0 \\
\hline Lumber, spruce & 115,933 & 115,933 & 0 & 0 \\
\hline Lumber, trusses & 2,129 & 2,129 & 0 & 0 \\
\hline Machinery & $15,133,438$ & $15,120,037$ & 13,400 & 0 \\
\hline Medical supplies & $3,797,108$ & $2,701,075$ & $1,096,033$ & 41 \\
\hline Modular unit(s) 10,000 & 1,922 & 1,922 & 0 & 0 \\
\hline Modular unit(s) 10,000 & 17,777 & 17,777 & 0 & 0 \\
\hline Paints \& lacquers & 388,984 & 388,984 & 0 & 0 \\
\hline Paper, waste & 229,784 & 229,784 & 0 & 0 \\
\hline Paper \& paper products & 183,986 & 183,986 & 0 & 0 \\
\hline Petroleum & 3,030 & 3,030 & 0 & 0 \\
\hline Petroleum, n.o.s., packaged & 8,596 & 62 & 8,534 & 13,800 \\
\hline Petroleum products & $16,511,543$ & $16,511,543$ & 0 & 0 \\
\hline
\end{tabular}


TABLE 2 (Continued)

\begin{tabular}{|c|c|c|c|c|}
\hline \multirow[b]{2}{*}{ Commodity } & \multicolumn{2}{|c|}{ Direct Impect } & \multicolumn{2}{|c|}{ Overestimate } \\
\hline & $\begin{array}{c}\text { Standard Method } \\
(S)\end{array}$ & $\begin{array}{l}\text { Our Method } \\
(\xi)\end{array}$ & & $\begin{array}{l}\text { Id Method } \\
\text { (\%) }\end{array}$ \\
\hline Petroleum solvents, packaged & 41,790 & 41,790 & 0 & $\mathbf{0}$ \\
\hline Phosphate chemicals, bagged & 502,069 & 1,331 & 500,738 & 37,632 \\
\hline Phosphate chemicals, bulk & $2,022,976,537$ & $1,367,637,281$ & $655,339,255$ & 48 \\
\hline Phosphate rock, bulk & $405,882,922$ & $172,862,154$ & $233,020,768$ & 135 \\
\hline Phosphoric acid & $622,201,488$ & $5,004,193$ & $617,197,295$ & 12,334 \\
\hline Pipe, plastic & 61,720 & 59,540 & 2,180 & 4 \\
\hline Pipe (other than steel) & 2,548 & 2,458 & 90 & 4 \\
\hline Plastic & 595,695 & 595,695 & 0 & $\mathbf{0}$ \\
\hline Plumbing supplies & 254,271 & 253,408 & 863 & 0 \\
\hline Plywood & 72,085 & 72,085 & $\mathbf{0}$ & $\mathbf{0}$ \\
\hline Rubber products & 287,140 & 287,140 & $\mathbf{0}$ & $\mathbf{0}$ \\
\hline Sand, silica, bagged & 2,812 & 2,812 & $\mathbf{0}$ & 0 \\
\hline Scrap metal & $28,376,301$ & $1,349,941$ & $27,026,360$ & 2,002 \\
\hline Ships, yachts, \& boats & 136,728 & 136,728 & 0 & $\mathbf{0}$ \\
\hline Steel, angles & 7,621 & 7,621 & 0 & $\mathbf{0}$ \\
\hline Steel, bars & 710,866 & 710,866 & $\mathbf{0}$ & 0 \\
\hline Steel, miscellaneous & $1,401,977$ & $1,401,977$ & 0 & $\mathbf{0}$ \\
\hline Steel, pipe & 480,369 & 480,368 & 2 & $\mathbf{0}$ \\
\hline Steel, pipe fittings & 327,779 & 279,408 & 48,370 & 17 \\
\hline Totals & $3,293,040,118$ & $1,708,013,852$ & $1,585,026,266$ & 93 \\
\hline
\end{tabular}

n.o.s. $=$ not otherwise specified.

sumed infinite price elasticity of demand is correct. Table 1, discussed earlier, gives the elasticities of demand for the commodities with non-zero entries in column 3 of Tables 2 and 3.

Before discussing the overall results, we note two technical points and explain how the direct impact of some of the commodities with extremely high elasticities remains positive. First, a constant-elasticity demand function approaches the price axis asymptotically, so quantity demanded can never be exactly zero, but it can be approximately zero, and the resulting direct impact can be zero when rounded to the nearest dollar, which is the case for the zero entries in column 3 of Tables 2 and 3.

Second, some of the percentage overestimates are zero while the dollar overestimates are not, e.g., buildings material in Table 2. As a practical matter, it is likely that some of these products would not have been exported or imported if the Port of Tampa were unavailable since the quantities demanded are relatively small. Nevertheless, we decided not to presume that this would happen, but to use the numbers generated by the estimation formulas as our estimates of direct impacts.

Finally, take the case of furniture imports as an example of how a commodity with a huge elasticity nevertheless produces a positive direct impact. In 
TABLE 3

Direct Impact of the Port of Tampa on Imports, Fiscal Year 1985-86 Standard Method vs. Our Method

\begin{tabular}{|c|c|c|c|c|}
\hline \multirow[b]{2}{*}{ Commodity } & \multicolumn{2}{|c|}{ Direct Impact } & \multicolumn{2}{|c|}{ Overestimate } \\
\hline & $\begin{array}{c}\text { Standard Method } \\
(\$)\end{array}$ & $\begin{array}{l}\text { Our Method } \\
(\boldsymbol{S})\end{array}$ & $\begin{array}{l}\text { Star } \\
\text { (S) }\end{array}$ & $\begin{array}{r}\text { Method } \\
\text { (\%) }\end{array}$ \\
\hline Aggregate, n.o.s. & 46,432 & 46,432 & $\mathbf{0}$ & 0 \\
\hline Aluminum & 201,701 & 518 & 201,183 & 38,851 \\
\hline Ammonia, anhydrous & $118,526,853$ & $45,458,754$ & $73,068,099$ & 161 \\
\hline Ammonium sulfate & $2,067,606$ & $2,059,950$ & 7,656 & 0 \\
\hline Asphalt, packaged & 43,471 & 43,471 & 0 & 0 \\
\hline Automobile(s) $10,000 \mathrm{lbs}$. & 114,518 & 4,499 & 110,020 & 2,446 \\
\hline Automobile(s) $10,000 \mathrm{lbs}$. & 907,277 & 2,033 & 905,244 & 44,520 \\
\hline Bananas & $41,648,375$ & $1,697,961$ & $39,950,414$ & 2,353 \\
\hline Building materials & 100,479 & 100,479 & 0 & 0 \\
\hline Calcium nitrate & $1,557,590$ & $1,122,459$ & 435,131 & 39 \\
\hline Caustic soda & $10,493,549$ & $10,493,549$ & 0 & $\mathbf{0}$ \\
\hline Cement, bulk & $8,954,165$ & $8,953,107$ & 1,057 & $\mathbf{0}$ \\
\hline Cement, clinker, bulk & $10,034,735$ & $2,212,980$ & $7,821,755$ & 353 \\
\hline Chemicals, packaged & 43,094 & 43,094 & 0 & 0 \\
\hline Citrus oil & $3,038,657$ & 24,944 & $3,013,713$ & 12,082 \\
\hline Clay, bagged & 2,526 & 112 & 2,413 & 2,146 \\
\hline Coal & $174,601,997$ & $167,322,517$ & $7,279,480$ & 4 \\
\hline Coffee & $4,115,666$ & $4,115,666$ & 0 & 0 \\
\hline Coke & 91,239 & 91,239 & 0 & 0 \\
\hline Commodities, n.o.s., packaged & $8,917,880$ & $\mathbf{8 , 9 1 7 , 8 8 0}$ & 0 & $\mathbf{0}$ \\
\hline Concentrate, apple, drummed & 824,940 & 54,538 & 770,402 & 1,413 \\
\hline Concentrate, citrus, bulk & $11,442,187$ & 506,185 & $10,936,001$ & 2,160 \\
\hline Concentrate, grapefruit & $1,034,268$ & 37,276 & 996,991 & 2,675 \\
\hline Concentrate, orange, drummed & 638,363 & 447,933 & 190,430 & 43 \\
\hline Concentrate, other & $1,145,661$ & 116,825 & $1,028,837$ & 881 \\
\hline Concentrate, pineapple & 13,328 & 881 & 12,448 & 1,414 \\
\hline Electrical equipment & 133,942 & 133,942 & 0 & 0 \\
\hline Essence & 248,762 & 246,973 & 1,789 & 1 \\
\hline Feed, bagged & $\mathbf{8 , 4 3 5}$ & 8,435 & 0 & 0 \\
\hline Fertilizer materials & $2,962,166$ & $2,882,429$ & 79,737 & 3 \\
\hline Food, n.o.s. & 664,922 & 494,215 & 170,707 & 35 \\
\hline Fruit, fresh & $11,537,298$ & $4,886,873$ & $6,650,425$ & 136 \\
\hline Furniture & 912,909 & 863,162 & 49,747 & 6 \\
\hline Glass products & 97,190 & 896 & 96,294 & 10,742 \\
\hline Grains, n.o.s., bulk & $21,691,828$ & $21,671,547$ & 20,280 & 0 \\
\hline Granite rock, bulk & $66,352,388$ & $13,545,525$ & $52,806,863$ & 390 \\
\hline Gypsum rock & $3,823,494$ & $3,749,699$ & 73,795 & 2 \\
\hline Hardboard & $1,170,174$ & $1,161,191$ & $\mathbf{8 , 9 8 2}$ & 1 \\
\hline Hardware & 680,124 & 112,453 & 567,671 & 505 \\
\hline Honey, packaged & 112,448 & $\mathbf{7 8 , 4 4 5}$ & 34,003 & 43 \\
\hline Household goods \& personal effects & 187,176 & 187,176 & 0 & 0 \\
\hline Iron sulfate & 438,882 & 438,882 & $\mathbf{0}$ & 0 \\
\hline Kierserite & 364,130 & 364,130 & 0 & 0 \\
\hline Limestone & 350,523 & 350,523 & $\mathbf{0}$ & 0 \\
\hline Liquor, beer & 13,037 & 13,037 & 0 & 0 \\
\hline Lumber, cedar & $3,294,747$ & $3,248,672$ & 46,074 & 1 \\
\hline Lumber, douglas fir & 154,742 & 154,742 & $\mathbf{0}$ & 0 \\
\hline Lumber, hemlock & $1,129,824$ & $1,127,373$ & 2,451 & 0 \\
\hline Lumber, hemlock-fir & $1,239,997$ & $1,234,964$ & 5,033 & 0 \\
\hline Lumber, n.o.s. & $15,464,493$ & $14,742,551$ & 721,942 & 5 \\
\hline Lumber, pine & $7,370,687$ & 337,494 & $7,033,193$ & 2,084 \\
\hline Lumber, spruce & $3,077,619$ & 77,418 & $3,000,201$ & 3,875 \\
\hline Lumber, tomato stakes & $13,750,960$ & 557,011 & $13,193,949$ & 2,369 \\
\hline
\end{tabular}


TABLE 3 (Continued)

\begin{tabular}{|c|c|c|c|c|}
\hline \multirow[b]{2}{*}{ Commodity } & \multicolumn{2}{|c|}{ Direct Impact } & \multicolumn{2}{|c|}{ Overestimate } \\
\hline & $\begin{array}{c}\text { Standard Method } \\
(\boldsymbol{(})\end{array}$ & $\begin{array}{l}\text { Our Method } \\
\text { (S) }\end{array}$ & $\begin{array}{l}\text { Stan } \\
(\theta)\end{array}$ & $\begin{array}{r}\text { ard Method } \\
\text { (\%) }\end{array}$ \\
\hline Meat, canned & 225,750 & 225,750 & 0 & 0 \\
\hline Meat (fresh or frozen) & $1,154,147$ & $1,032,579$ & 121,568 & 12 \\
\hline Medical supplies & 26,593 & 26,593 & 0 & 0 \\
\hline Metals & 33,657 & 33,657 & 0 & $\mathbf{0}$ \\
\hline Minerals \& ores, bulk & $1,036,189$ & $1,036,189$ & 0 & 0 \\
\hline Newsprint and cores & $10,959,693$ & $9,053,932$ & $1,905,762$ & 21 \\
\hline Nitrate of soda & $2,052,323$ & $1,907,756$ & 144,567 & 8 \\
\hline Paints and lacquers & 30,642 & 994 & 29,647 & 2,982 \\
\hline Paper \& paper products & 8,541 & 8,541 & 0 & $\mathbf{0}$ \\
\hline Petroleum products & $1,538,342,030$ & $785,049,567$ & $753,292,463$ & 96 \\
\hline Plastics & 902,089 & 902,089 & 0 & 0 \\
\hline Plumbing supplies & 9,878 & 9,878 & 0 & 0 \\
\hline Plywood & $4,414,492$ & $4,294,878$ & 119,615 & 3 \\
\hline Potash, bagged & 72,682 & 72,682 & 0 & 0 \\
\hline Potash, bulk & $3,813,399$ & $3,802,809$ & 10,590 & 0 \\
\hline Potassium nitrate, bagged & $2,725,271$ & 95,038 & $2,630,233$ & 2,768 \\
\hline Potassium nitrate, bulk & $3,525,288$ & 916,705 & $2,608,583$ & 285 \\
\hline Salt, bulk & 720,146 & 720,146 & 0 & 0 \\
\hline Scrap metal & 10,360 & 10,360 & 0 & 0 \\
\hline Seafood, fresh \& frozen & $6,005,228$ & 54,539 & $5,950,688$ & 10,911 \\
\hline Seafood, prepared \& preserved & $23,833,386$ & 12,027 & $23,821,359$ & 198,061 \\
\hline Ships, yachts, \& boats & 18,918 & 18,179 & 739 & 4 \\
\hline Slag & $3,562,898$ & $2,845,764$ & 717,134 & 25 \\
\hline Steel, angles & 507,030 & 462,585 & $\mathbf{4 4 , 4 4 4}$ & 10 \\
\hline Steel, bars & $1,765,062$ & 7,357 & $1,757,705$ & 23,891 \\
\hline Stcel, beams & $13,332,405$ & $4,658,237$ & $8,674,168$ & 186 \\
\hline Steel, billets, blooms & 78,607 & 578 & 78,029 & 13,506 \\
\hline Steel, coils & $13,943,100$ & $4,181,197$ & $9,761,903$ & 233 \\
\hline Steel, miscellaneous & $34,922,784$ & $33,381,515$ & $1,541,269$ & 5 \\
\hline Steel, pipe & $32,431,556$ & $7,586,343$ & $24,845,213$ & 327 \\
\hline Steel, pipe fittings & 94,288 & 61,049 & 33,239 & 54 \\
\hline Steel, plates \& sheets & $36,542,527$ & $8,809,544$ & $27,732,983$ & 315 \\
\hline Steel, strip & 702,816 & 702,792 & 24 & $\mathbf{0}$ \\
\hline Steel, tubing & $1,417,674$ & $1,366,502$ & 51,173 & 4 \\
\hline Steel, wire rod & $1,943,952$ & $1,734,550$ & 209,402 & 12 \\
\hline Sulphur, liquid & $370,479,932$ & $159,670,195$ & $210,809,737$ & 132 \\
\hline Textiles & $2,033,071$ & $1,907,278$ & 125,793 & 7 \\
\hline Tile & 474,910 & 474,910 & 0 & 0 \\
\hline Tin plate & 305,944 & 228,226 & 77,719 & 34 \\
\hline Tobacco, manufactured & $2,258,358$ & $2,258,358$ & 0 & 0 \\
\hline Tobacco, unmanufactured & 934,940 & 745,401 & 189,539 & 25 \\
\hline Tools & 33,576 & 33,576 & 0 & 0 \\
\hline Vegetables, fresh & 8,496 & 8,496 & 0 & 0 \\
\hline Totals & $2,676,549,675$ & $1,367,969,979$ & $1,308,579,696$ & 96 \\
\hline
\end{tabular}

n.o.s. = not otherwise specified. 
fact, for four of the five counties in our impact area, our estimation formula produced zero as the direct impact of this product. However, for the remaining county, the local delivered price of furniture would not have changed and, hence, that county would have continued to import the same amount as if the Port of Tampa were available.

The delivered price remains the same for this county because the rise in the inland transportation rate is exactly offset by the fall in the overseas transportation rate, whereas for the other counties the rise in the inland transportation rate out weighs the fall in the liner rate so that the delivered price rises.

The overseas transportation rate falls because the import would arrive from Europe at a port on the east coast of Florida, rather than the Port of Tampa, which is on the west coast of Florida. This would make for a shorter overseas trip and a lower rate. The county for which the delivered price was unchanged was the eastern-most county in our impact area. Consequently, the rise in inland transportation rates would be lowest for this county.

A similar situation occurs for some of the other commodities with extremely high elasticities, but in all of these cases, e.g., bagged clay and new and used cars, the change in delivered price is extremely small, rather than zero, as with furniture for one county.

We turn now to the results. The total direct impact of the Port of Tampa on exports was slightly more than $\$ 1.7$ billion in fiscal year 1985-86. Exporters of phosphate chemicals would have been most adversely affected by the port's closure, the value of their exports, both foreign and domestic, declining nearly $\$ 1.4$ billion. Exporters of phosphate rock would also have been affected severe ly, the value of their output declining nearly $\$ 173$ million. The rest of the direct impact of exports is spread over a wide variety of products, ranging from live cattle to personal effects of households.

If we had assumed an infinite price elasticity of demand for all exported commodities, i.e., had we used the standard methodology, the direct impact of the Port of Tampa on exports would have been nearly $\$ 3.3$ billion, an overestimate of nearly $\$ 1.6$ billion or 93 percent.

Because the Tampa Bay area is a major producer of phosphate rock, phosphate chemicals, and phosphoric acid, the price elasticities of world demand for the area's phosphate products are not as large as those of commodities for which the area is a minor supplier. Consequently, it might be suspected that the presence of the phosphate industry in the Tampa area tends to result in a greater overestimate than otherwise would be the case. Subtracting the phosphate impacts (phosphate chemicals, phosphate rock, and phosphoric acid) of $\$ 1,545,504,959$ by our method and $\$ 3,051,563,016$ by the standard method from both impact totals produces a non-phosphate impact of $\$ 162,508,893$ by our method and 
$\$ 241,477,102$ by the standard method, resulting in an overestimate of 49 percent. As suspected, the overestimate is lower but still significant.

As can be seen in Table 3, the direct impact of the Port of Tampa on imports was nearly $\$ 1.4$ billion. Imports of petroleum products would have been most adversely affected by the Port's closure during fiscal year 1985-86, falling by over $\$ 785$ million. Coal and liquid sulphur imports would also have been hard hit, falling by over $\$ 167$ million and nearly $\$ 160$ million, respectively. Had the standard methodology been used, the total direct impact of the Port of Tampa on imports in fiscal year 1985-86 would have been nearly $\$ 2.7$ billion, an overestimate of over $\$ 1.3$ billion or 96 percent.

\section{v. CONCLUSION}

The contention of this paper is that port direct impacts are overestimated unless the price elasticities of demand for exports and imports are taken into account. We think this point is theoretically indisputable, but the question remains whether in practice the benefits of performing the additional work outweigh the costs. As this paper has indicated, estimating the impact formulas of Equations (1) and (2) requires a good deal of data collection and processing, more than with the standard approach. We cannot provide a general answer to the benefit-cost question, but we can give an indication of the importance of our methodology in the case of the economic impact of the Port of Tampa.

Although a substantial number of products that were exported from and imported into the Tampa area have price elasticities of demand of infinity, had the demand for the remaining products been assumed to be infinity, the direct impact of the Port of Tampa on exports would be have overestimated by $\$ 1.6$ billion or 93 percent, while the direct impact of imports would have been overestimated by $\$ 1.3$ billion or 96 percent.

\section{REFERENCES}

Commodity Research Bureau. 1987 CRB Commodity Yearbook. New York: Commodity Research Bureau, 1987.

Davis, H. Craig. "Regional Port Impact Studies: A Critique and Suggested Methodology." Transportation Journal 23 (1983): 61-71.

Deaton, A.S. "The Measurement of Income and Price Elasticities." European Economic Review 6 (1975): 261-273. 
Deaton, Angus, and John Muelbauer. Economics and Consumer Behavior. Cambridge: Cambridge University Press, 1980.

Department of International Economic and Social Affairs, Statistical Office of the United Nations. Industrial Statistics Yearbook 1984. New York: United Nations, 1986.

1985 International Trade Statistics Yearbook. New York: United Nations, 1987.

DeSalvo, Joseph S., and Debra L. Fuller. The Economic Impact of the Port of Tampa. Tampa, Fla.: Center for Economic and Management Research, 1988.

Florida Department of Labor and Employment Security. Bureau of Research and Information. Edited ES-202, Quarterly County Report on Employment and Wages Covered under the Florida Unemployment Compensation Law, State of Florida. Quarter 4, 1985 - Quarter 3, 1986.

Griliches, Zvi. "The Demand for a Durable Input: Farm Sectors in the United States, 1921-57." In The Demand for Durable Goods edited by A. C. Harberger. Chicago: The University of Chicago Press, 1960.

. "The Demand for Fertilizer: An Economic Interpretation of a Technical Change." Journal of Farm Economics 40 (1958): 591-606.

Houthakker, H.S., and Lester D. Taylor. Consumer Demand in the United States, 1929-1970. Cambridge: Harvard University Press, 1966.

Maurice, S. Charles, and Owen R. Phillips. Economic Analysis: Theory and Application. 6th ed. Homewood, Ill.: Richard D. Irwin, Inc., 1992.

Miller, Ronald E., and Peter D. Blair. Input-Output Analysis: Foundations and Extensions. Engelwood Cliffs, N.J.: Prentice-Hall, Inc., 1985.

Phlips, Louis. Applied Consumption Analysis. Amsterdam: North-Holland Publishing Co., 1983.

Port of Tampa. Port of Tampa, Florida, Fiscal Year Cargo Report, October 1, 1985 - September 30, 1986. Tampa: Port of Tampa, 1986.

Robinson, Vernon L. "An Econometric Model of Softwood Lumber and Stumpage Markets, 1947-1967." Forest Science 20 (1974): 171-179.

Shiells, Clinton R., Robert M. Stern, and Alan V. Deardorff. "Estimates of the Elasticities of Substitution between Imports and Home Goods in the United States." Weltwirtschaf fliches Archiv Review of World Economics 122 (1986): 497- 519.

Shipping Digest. New York: Geyer-McAllister Publications, Inc., November 2, 1987.

Stone, Richard. The Measurement of Consumers' Expenditure and Behaviour in the United Kingdom, 1920-1938. Cambridge: Cambridge University Press, 1954.

The Florida Shipper. Miami: Sea-Barge Group, Inc., October 26, 1987. 
The Journal of Commerce and Commercial Shipyards. New York: Knight-Ridder, November 4, 1987.

Temple, Barker \& Sloane, Inc., Recht Hausrath \& Associates, and Regional Science Research Institute. Port Economic Impact Kit. Washington, D.C.: Maritime Administration, Office of Port and Intermodal Development, 1985.

U.S. Department of Commerce. Bureau of the Census. Foreign Trade Division. EM 563 and FAS 154 Microfiche. Washington, D.C.: U.S. Department of Commerce, 1986a.

Foreign Trade Division. SM 305 Magnetic Tape. Washington, D.C., U.S. Department of Commerce, 1986b.

. Statistical Abstract of the United States 1987, 107th Edition. Washington, D.C.: U.S. Government Printing Office, 1986 c.

Yntema, Theodore O. "The Price Elasticity of Demand for Steel." In Price Theory in Action, edited by D. S. Watson and M. Getz. Prospect Heights, Ill.: Waveland Press, Inc., 1981. 